Finanse, Rynki Finansowe, Ubezpieczenia nr 2/2017 (86)

DOI: $10.18276 /$ frfu.2017.86-30

s. $363-374$

\title{
Stock market liquidity and returns on the Warsaw Stock Exchange: An introductory survey
}

\author{
Szymon Stereńczak*
}

\begin{abstract}
Purpose - On developed capital markets, the effect of stock market liquidity on expected stock returns is well documented. However, there is still lack of comprehensive analysis in this field for Polish stock market. Previous studies made on the Warsaw Stock Exchange are ambiguous (see Gajdka, Gniadkowska, Schabek, 2010; Olbryś, 2014). The main goal of this paper is to analyze the impact of stock liquidity on its returns on the Warsaw Stock Exchange during the period 2011-2015.

Design/Methodology/Approach - To measure the liquidity, Amihud illiquidity measure was computed. Timeseries regression of excess return on realized and unexpected liquidity was used. Besides, the cross-sectional and pooled cross-sectional time-series regression to investigate the relationship between liquidity and stock returns was applied.

Findings - The paper shows that illiquidity affects stock returns in the time-series and cross-section. This effect persists after controlling for size and book-to-market ratio.

Originality/Value - The author is not aware of other studies using similar approach on the Polish capital market. Presented results justify further and more advanced research on the relationship between stock market liquidity and stock returns on the Warsaw Stock Exchange.
\end{abstract}

Keywords: stock liquidity, stock returns, Warsaw Stock Exchange, pricing of liquidity

\section{Introduction}

A lot of studies on the effects of illiquidity on expected stock returns have been done since Amihud and Mendelson's (1986) seminal paper. Most of these studies have been conducted for US and other developed stock markets. Few of them are related to emerging markets, especially to the Warsaw Stock Exchange. This paper, to the best of the author's knowledge, is one of the first concerning the relationship between stock liquidity and returns on Polish capital market ${ }^{1}$.

Liquidity is a broad and elusive concept which is better explained by its dimensions. Despite more than thirty years since Kyle (1985) has started his research on liquidity, there is still "no single unambiguous, theoretically correct or universally accepted definition of

\footnotetext{
* mgr Szymon Stereńczak, Uniwersytet Ekonomiczny w Poznaniu, Wydział Zarządzania, e-mail: szymon. sterenczak@ue.poznan.pl

1 Previous studies using data from polish capital market was Gajdka, Gniadkowska and Schabek (2010), Donadelli and Prosperi (2011), Lischewski and Voronkowa (2012) and Olbryś (2014).
} 
liquidity" (Baker, 1996). In general, liquidity is defined as the ease of trading large quantities (e.g. of shares) quickly, at low cost and without unfavorable price impact (Pastor, Stambaugh, 2003). In practice, investors face illiquidity, i.e. lack of perfect liquidity. Hence, an agent willing to trade faces a trade-off: trade immediately incurring high transaction costs and price impact, or trade patiently splitting the order into small pieces, and incur opportunity costs (Amihud, Mendelson, 1986; Huberman, Stanzl, 2005). Investors wish to be compensated for those costs, hence less liquid stocks should yield higher returns.

Previous studies on pricing of illiquidity suggest that it can be priced in two ways: as a stock characteristic or as a risk factor. Authors referring to that first approach (e.g. Amihud, Mendelson, 1986; Brennan, Subrahmanyam, 1996; Datar, Naik, Radcliffe, 1998; Amihud, 2002; Chordia, Roll, Subrahmanyam, 2002; Hasbrouck, 2009) find that the level of liquidity is priced. In the former approach (developed by Sadka, 2002; Pastor, Stambaugh, 2003; Acharya, Pedersen, 2005; Liu, 2006; Korajczyk, Sadka, 2008) the priced factor was not the level of illiquidity, but the liquidity risk, i.e. returns' sensitivity to innovations in marketwide illiquidity.

The paper refers to the extant literature by applying the Amihud's (2002) and Datar, Naik and Radcliffe's (1998) framework on Polish capital market. Using their methodology, cross-sectional, time-series and pooled cross-sectional time-series regressions were ran. This has been done to investigate whether less liquid stocks yield higher returns than more liquid stocks. Empirical findings suggest that illiquidity is positively related to stock returns in time-series and cross-section, even after controlling for size and book-to-market ratio. Those results are consistent with Amihud (2002) and Datar, Naik and Radcliffe (1998).

The rest of the paper is organized as follows. Section I contains a brief literature overview. Data and methodology are presented in Section II. Empirical findings are shown in section III, and the final section is the study conclusion. The study was financed by the National Science Centre, Poland as a research project (2015/19/D/HS4/01950).

\section{Literature overview}

The effects of illiquidity on stock returns have been broadly investigated since Amihud and Mendelson's (1986) seminal paper. They presented a model relating returns to transaction costs measured by bid-ask spread. The model assumed that the investor willing to transact faces a tradeoff: wait to transact at a favorable price or transact immediately at the current bid or ask prices quoted by market maker. Hence, bid-ask spread is a natural measure of liquidity: the higher the spread, the less liquid the stock. There are two basic conclusions from this research. First, due to transaction costs there exists so called clientele effect: less liquid stocks are held by long-term investors while more liquid stocks are traded by shortterm investors. Due to clientele effect, stock returns are "growing and concave function of spread" (Amihud, Mendelson, 1986).

Brennan and Subrahmanyam (1996) developed the Amihud and Mendelson's (1986) framework by splitting transaction costs into fixed and variable components. They found that 
fixed transaction costs are not related to stock returns, but they proved the existence of concave relationship between stock returns and variable component of transaction costs. Datar, Naik and Radcliffe (1998), using turnover rate (i.e. number of shares traded divided by the number of shares outstanding), checked whether stock returns are related to liquidity. Their results supported the predictions of the model created by Amihud and Mendelson (1986).

Abovementioned studies investigated the effect of liquidity on the cross-section of stock returns, neglecting its effect on time-series. This gap was filled by Amihud (2002). He employed a new liquidity proxy which is positively and strongly related to microstructure measures of liquidity, i.e. Kyle's $\lambda$ - measure for price impact, and fixed component of transaction costs. The study documented a strong and positive impact of illiquidity on the cross-section of ex-ante stock returns. There was also shown that liquidity affects expected stock returns in the time-series: excess returns are the growing function of expected illiquidity and unexpected illiquidity has a negative impact on contemporaneous returns.

Pastor and Stambaugh (2003) implemented a new approach to liquidity pricing. In their opinion, the level of liquidity is not important for the asset pricing since it varies in the timeseries. They found that the priced factor is the liquidity risk, i.e. sensitivity of individual stock returns to changes in aggregate market liquidity. In this study, a new measure of liquidity has been developed. It is computed by regressing contemporaneous excess stock return on return and trading volume on the previous day. Empirical results support the hypothesis that liquidity risk is an important variable in asset pricing.

Another look on the liquidity risk premium was presented by Acharya and Pedersen (2005). Illiquidity risk has been decomposed into three forms (Acharya, Pedersen, 2005):

1. commonality in liquidity (covariance of individual stock liquidity and aggregate market liquidity),

2. return's sensitivity to changes in marketwide liquidity (covariance of individual stock returns and market liquidity),

3. liquidity's sensitivity to market returns (covariance of individual stock liquidity and market returns).

By estimating their Liquidity-Adjusted Capital Assets Pricing Model (L-CAPM), Acharya and Pedersen (2005) noted that all three sources of illiquidity risk premium are important, but the most important for the asset pricing is the liquidity's sensitivity to stock returns.

All of the studies mentioned above were conducted using data from US stock markets, which are arguably the most developed and liquid in the world. Bekaert, Harvey and Lundblad (2007) noted that liquidity should have greater effects on stock returns on less liquid markets, especially on emerging ones. Few studies have been conducted on less developed capital markets, e.g. Polish. Milo and Wawruszczak $(2005,2006)$ and Kucharski $(2009,2010)$ have analyzed the impact of trading volume signed by the excess return on the excess return at the following day. Studies of Garsztka $(2011,2012)$ were to include liquidity risk into the Sharpe optimization problem. Będowska-Sójka (2016) investigated how liquidity changes at the inflow of new information which has a direct impact on the pricing of liquidity. 
One of the first researches explicitly and directly investigating the relationship between stock liquidity and returns including data from the Warsaw Stock Exchange (WSE) was a study by Donadelli and Prosperi (2011), focused on 12 developed and 19 emerging equity markets. Two other papers tackling the problem of liquidity (or liquidity risk) pricing on the Polish capital market were Gajdka, Gniadkowska and Schabek (2010), Lischewski and Voronkova (2012) and Olbryś (2014). Gajdka, Gniadkowska and Schabek (2010) found that bid-ask spread has a significant effect on stock returns ${ }^{2}$. Three other mentioned studies show that illiquidity risk is not priced on the WSE.

This paper contributes to the extant literature at least in two ways. Firstly, by investigating the relationship between the level of illiquidity and stock returns on the Polish capital market. Previous studies using data from the WSE applied another framework, i.e. investigated pricing of liquidity as a risk factor and not as a stock characteristic. Secondly, it is worth noting that Polish market is an order-driven market while NYSE and Nasdaq are "hybrid quote-driven markets". Such a difference in market structure may be possibly important for liquidity pricing (Marshall, Young, 2003).

\section{Data and methodology}

The impact of liquidity on stock returns was investigated for stocks listed on the Warsaw Stock Exchange in the years 2011-2015. Firms' financial data have been gathered from Notoria Serwis database. Quotation data, needed primarily to compute Amihud illiquidity ratio, come from the archives of session results provided by Warsaw Stock Exchange. Rates of return are computed daily as simple rates of return. In order to calculate rates of return needed to estimate the level of liquidity, at first prices of shares have been adjusted for corporate actions, i.e. dividends, splits, reverse-splits and subscription rights. Firms from financial sectors (i.e. banks, insurance companies), companies with lack of financial data needed to compute value of capitalization (proxy for firm size) and book-to-market value (proxy for growth opportunities) have been excluded from the sample. An additional condition of including the company into the research sample was availability of data on returns and volumes for at least 185 days per year or at least 15 days per month. Total number of non-financial companies listed on the Warsaw Stock Exchange during the study period and included into the research sample is 425 , which gives 1577 yearly observations and 14705 monthly observations.

The proxy for liquidity was the Amihud illiquidity ratio calculated as (Amihud, 2002):

where:

$$
I L L I Q_{i y}=\frac{1}{D_{i y}} \sum_{t=1}^{D_{i y}} \frac{\left|r_{i d y}\right|}{V o l_{i d y}}
$$

2 Findings of Gajdka, Gniadkowska and Schabek (2010) support the Amihud and Mendelson's (1986) model: stock returns are growing and concave function of bid-ask spread. 
$\mathrm{D}_{\text {iy }}$ - number of days for which data are available for stock $i$ in year $y$,

$\mathrm{r}_{\text {idy }}$ - return on stock $i$ on day $d$ of the year $y$,

$\mathrm{Vol}_{\text {idy }}$ - trading dollar volume on stock $i$ on day $d$ of the year $y$.

Illiquidity ratios have been computed monthly and annually and the stocks have been used to calculate the average illiquidity for a given month or year if they have had returns and volume for more than 15 and 185 days during month and year-respectively. This is needed to avoid big biases in estimated value of liquidity measure. To make data more legible, computed illiquidity ratios were multiplied by $10^{5}$ and logarithmized ${ }^{3}$. Amihud (2002) multiplied values of his measure by $10^{6}$ but it should be noted that NYSE is a far more liquid market than the WSE and has smaller values of illiquidity.

Following Datar, Naik and Radcliffe (1998) and Amihud (2002), the cross-section and pooled cross-section time-series models have been estimated where stock returns are the function of stock characteristics:

$$
\begin{gathered}
r_{i t}=a_{0 t}+\sum_{k=1}^{K} a_{k t} x_{i t}+\varepsilon_{i t} \\
r_{i m t}=b_{0 m t}+\sum_{k=1}^{K} b_{k m t} x_{i m, t-1}+\varepsilon_{i m t}
\end{gathered}
$$

where $i$ denotes stock, $K$ denotes number of stock characteristics $x, m$ and $t$ denotes month and year respectively, and $\varepsilon$ denotes random component which is assumed to be normally distributed with mean 0 and variance $\sigma^{2}\left(\mathrm{~N}\left(0, \sigma^{2}\right)\right)$ and serially uncorelated. Estimated parameters of cross-sectional models have been averaged to obtain the average effect of each stock characteristic on stock returns. Following Litzenberger and Ramaswamy (1979) pooled estimators have been computed as a weighted average of monthly estimates, where the weights were proportional to the reciprocal of the variance of these yearly or monthly estimates.

Then, to check whether illiquidity is priced over time, following Amihud (2002), the time-series model has been estimated:

$$
r_{M, m}^{e}=c_{0}+c_{1} \ln A I L L I Q_{m-1}+c_{2} \ln A I L L I Q_{m}^{U}+\varepsilon_{m}
$$

where:

$\mathrm{r}_{\mathrm{M}, \mathrm{m}}^{\mathrm{e}}-$ market excess return in month $m$,

AILLIQ $_{\mathrm{m}}$ - average market illiquidity in month $m$, computed as an equally weighted average of stock illiquidity, $\ln$ AILLIQ $_{\mathrm{m}}^{\mathrm{U}}$ - unexpected illiquidity in month $m$, the residual $v_{m}$ from:

$$
\ln A I L L I Q_{m}=d_{0}+d_{1} \ln A I L L I Q_{m-1}+v_{m}
$$

\footnotetext{
3 Empirical distribution of Amihud measure in the given sample is log-normal distribution (not reported). Hence, values of liquidity measure have been logarithmized to provide better properties of model parameters estimators.
} 
$\varepsilon_{m}, v_{m}$ - random components which are assumed to be normally distributed with mean 0 and variance $\sigma^{2}\left(\mathrm{~N}\left(0, \sigma^{2}\right)\right)$ and serially uncorelated.

By estimating this model, two hypotheses may be tested: the effect of expected illiquidity on stock returns is positive and unexpected illiquidity negatively affects stock returns. This implies that $c_{1}$ is expected to be positive and $c_{2}$ to be negative.

\section{Empirical findings}

In this section there will be investigated the effect of liquidity measured by the Amihud's ratio on stock returns, with and without controlling for size and book-to-market ratio. Table 1 summarizes the regression coefficients for equation (2) and Table 2 summarizes the slopes for monthly regressions (equation (3)). Panel A contains averaged estimates of cross-sectional regressions and Panel B contains pooled cross-sectional time-series coefficients.

Models M5 and M13 include panel data and have been estimated using OLS method. Due to the fact that residuals from the models estimated using OLS are not normally distributed, (what may cause erroneous assessment of statistical significance of parameters) ${ }^{4}$ and the heteroscedasticity of random component ${ }^{5}$, models $M 6$ and M14, also including panel data, were estimated using GLS. Due to the poor quality of models estimated using GLS, panel models with fixed effects have been estimated ${ }^{6}$. Models $M 7-M 8$ contain fixed effects for firms and in models M15-M16 period dummies were included additionally.

In models $M 1-M 8$ presented in Table 1 book-to-market value and firm's size have been estimated from data at the end of the year $t$ and liquidity was estimated using data from year $t$. Statistics for number of observations, adjusted R-squared, Durbin-Watson statistic and Hannan-Quinn Information Criterion are given only for models M5-M8 and M13-M16 due to the fact that coefficients in M1-M4 and M9-M12 are the averaged value of five and forty eight cross-sectional regressions. In models $M 9-M 16$ presented in Table 2 liquidity was computed using data from month $m$ and book-to-market value and firm's size were estimated from data at the end of the year $t-1$. The proxy for size was a natural logarithm of the firm's market capitalization.

\footnotetext{
4 Doornik-Hansen statistics equal 4754.41 for yearly and 14294.83 for monthly data.

5 Values of statistics of White test for yearly and monthly data are equal 130.034 and 204.752 respectively.

6 Hausman test indicated that fixed effects are more appropriate than random effects. Values of $\mathrm{H}$ statistics are equal to 24.636 for yearly data and 72.481 for monthly data.
} 


\section{Table 1}

Slopes of yearly cross-sectional and pooled cross-sectional time-series regression of returns

\begin{tabular}{|c|c|c|c|c|}
\hline \multicolumn{5}{|l|}{ Panel A } \\
\hline Model & $M 1$ & M2 & $M 3$ & M4 \\
\hline Intercept & $\begin{array}{l}-0,00021^{* * *} \\
(6,563)\end{array}$ & $\begin{array}{l}-0,00003 \\
(1,330)\end{array}$ & $\begin{array}{l}-0,00453 * * * \\
(13,938)\end{array}$ & $\begin{array}{l}-0,00202 * * * \\
(8,112)\end{array}$ \\
\hline Illiquidity & $\begin{array}{l}0,00002^{* *} \\
(2,222)\end{array}$ & $\begin{array}{l}0,00001 * * \\
(2,069)\end{array}$ & $\begin{array}{l}0,00011^{* * *} \\
(9,167)\end{array}$ & $\begin{array}{l}0,00005^{* * *} \\
(6,804)\end{array}$ \\
\hline $\mathrm{B} / \mathrm{MV}$ & & $\begin{array}{l}0,00002 * * * \\
(30,010)\end{array}$ & & $\begin{array}{l}0,00003^{* * *} \\
(31,792) \\
\end{array}$ \\
\hline Size & & & $\begin{array}{l}0,00023 * * * \\
(13,529)\end{array}$ & $\begin{array}{l}0,00010^{* * * *} \\
(8,041)\end{array}$ \\
\hline \multicolumn{5}{|l|}{ Panel B } \\
\hline Model & M5 & M6 & $M 7$ & $M 8$ \\
\hline Intercept & $\begin{array}{l}-0,00499 \text { *** } \\
(8,433)\end{array}$ & $\begin{array}{l}-0,00252^{* * * *} \\
(3,584)\end{array}$ & $\begin{array}{l}-0,01170^{* * *} \\
(7,962)\end{array}$ & $\begin{array}{l}-0,01186^{* * *} \\
(7,944)\end{array}$ \\
\hline Illiquidity & $\begin{array}{l}0,00012 * * * \\
(6,026)\end{array}$ & $\begin{array}{l}0,00008^{* * *} \\
(4,898)\end{array}$ & $\begin{array}{l}0,00010^{* * * *} \\
(2,977)\end{array}$ & $\begin{array}{l}0,00010^{* * *} \\
(2,931)\end{array}$ \\
\hline $\mathrm{B} / \mathrm{MV}$ & $\begin{array}{l}0,00004 * * * \\
(36,800)\end{array}$ & $\begin{array}{l}0,00005^{* * *} \\
(3,580)\end{array}$ & $\begin{array}{l}0,00004 * \\
(33,390) \\
\end{array}$ & $\begin{array}{l}0,00004^{* * *} \\
(33,140)\end{array}$ \\
\hline Size & $\begin{array}{l}0,00025^{* * * *} \\
(8,241)\end{array}$ & $\begin{array}{l}0,00013 * * * \\
(3,623)\end{array}$ & $\begin{array}{l}0,00061^{* * *} \\
(7,854)\end{array}$ & $\begin{array}{l}0,00062^{* * *} \\
(7,758)\end{array}$ \\
\hline Firms' fixed effects & No & No & Yes & Yes \\
\hline Years' dummies & No & No & No & Yes \\
\hline Number of obs. & 1577 & 1577 & 1577 & 1577 \\
\hline Adj. R-squared & 0.4652 & 0.0173 & 0.4950 & 0.4964 \\
\hline $\mathrm{HQC}$ & -15127.17 & 11566.58 & -14257.86 & -14246.33 \\
\hline
\end{tabular}

T-statistics are given in parentheses

$*, * *, * * *$ denotes statistical significance at level $10 \%, 5 \%$ and $1 \%$ respectively

Source: own development.

Table 2

Slopes of monthly cross-sectional and pooled cross-sectional time-series regression of returns

\begin{tabular}{lllll}
\hline Panel A & & & & \\
\hline Model & $M 9$ & $M 10$ & $M 11$ & $M 12$ \\
\hline Intercept & $0,00060^{* * *}$ & $0,00052^{* * *}$ & $0,00340^{* * *}$ & $0,00148^{* * *}$ \\
& $(65,263)$ & $(54,141)$ & $(39,543)$ & $(14,896)$ \\
\hline Illiquidity & $0,00009^{* * *}$ & $0,00005^{* * *}$ & $0,00005^{* * *}$ & $0,00004^{* * *}$ \\
& $(33,506)$ & $(17,008)$ & $(14,708)$ & $(12,948)$ \\
\hline B/MV & & $0,00002^{* * *}$ & & $0,00002^{* * *}$ \\
& & $(50,248)$ & & $(44,948)$ \\
\hline Size & & $-0,00014^{* * *}$ & $-0,00005^{* * *}$ \\
& & & $(31,086)$ & $(8,764)$ \\
\hline
\end{tabular}




\begin{tabular}{lllll}
\hline Panel B & & & & \\
\hline Model & $M 13$ & $M 14$ & $M 15$ & $M 16$ \\
\hline Intercept & 0,00080 & $0,00132^{*}$ & $0,00226^{* * *}$ & $0,00331^{* * *}$ \\
& $(1,204)$ & $(1,948)$ & $(2,612)$ & $(3,511)$ \\
\hline Illiquidity & $0,00004^{*}$ & 0,00003 & $-0,00010^{* *}$ & 0,00003 \\
& $(1,667)$ & $(1,601)$ & $(2,509)$ & $(0,665)$ \\
\hline B/MV & $0,00003^{* * *}$ & 0,00002 & $0,00001^{* * *}$ & $0,00002^{* * *}$ \\
& $(13,220)$ & $(1,252)$ & $(6,574)$ & $(7,165)$ \\
\hline Size & $-0,00001$ & $-0,00003$ & $-0,00008^{*}$ & $-0,00008^{*}$ \\
& $(0,266)$ & $(1,006)$ & $(1,817)$ & $(1,801)$ \\
\hline Firms' fixed effects & No & No & Yes & Yes \\
\hline Months' dummies & No & No & No & Yes \\
\hline Number of obs. & 14705 & 14705 & 14705 & 14705 \\
\hline Adj. R-squared & 0.0129 & 0.0004 & 0.0042 & 0.0774 \\
\hline HQC & -98239.02 & 89106.52 & -97408.32 & -99514.54 \\
\hline
\end{tabular}

$t$-statistics are given in parentheses

$*, * *, * * *$ denotes statistical significance at level $10 \%, 5 \%$ and $1 \%$ respectively

Source: own development.

As shown in the tables above, liquidity has an effect on stock returns. With the exception of one model (i.e. M15), parameters for illiquidity are positive and ranging from 0,00001 to 0,00012 . This means that less liquid stocks have higher returns. This effect persists after controlling for size and book-to-market ratio, however, in cross-sectional models for monthly data, effect of illiquidity on stock returns attenuates after controlling for additional variables. It has to be noted that in model M15 illiquidity has a negative and significant impact on stock returns, which is a little bit surprising.

To avoid biases, in models where book-to-market ratio was included, firms with negative book value of equity were excluded from the sample. Signs of parameters for book-to-market ratio in all models are consistent with expectations, i.e. positive. Surprisingly, yearly crosssectional and pooled cross-sectional time-series estimates of parameters for size are positive. This is contrary to the concept that smaller stocks have higher stock returns.

Due to the ambiguity of presented results of the study conducted on the cross-sectional effect of liquidity on stock returns, an alternative model has been estimated. It is the same as the model M16, but with one-month lag for illiquidity. Firms' fixed effects and months' dummies have been included. The estimation of this model provides the following results ( $t$-statistics for parameters are given in the parentheses):

$$
\begin{gathered}
\hat{r}_{i m t}=0,00234+0,00030 \ln I L L I Q_{i m-1, t}+0,00001 B M V_{i m, t-1}-0,00006 \ln M V_{i m, t-1} \\
(2,427)(7,378) \\
(5,587)
\end{gathered}
$$

As expected, the model exhibits a positive impact of illiquidity on stock returns. That means that less liquid stocks have higher returns, even after controlling for book-to-market ratio and size. Parameters for size and book-to-market value are negative and positive re- 
spectively, which is consistent with the notion that bigger firms yield lower returns and stocks with higher growth potential yield higher returns.

To summarize this part, it should be noted that it is highly plausible that liquidity has an effect on the cross-section of stock returns on the Warsaw Stock Exchange. Not in all models M1-M16 parameters for illiquidity were positive or statistically significant. The model presented in equation (6) confirms the hypothesis that less liquid, growth and smaller stocks yield higher returns on the Polish stock market.

Next, to investigate the effect over time of illiquidity on market returns, two hypotheses will be tested:

1. expected illiquidity positively affects market excess returns,

2. unexpected illiquidity has a negative effect on market excess returns.

Such hypothesizing implies that the value of parameter $c_{l}$ in equation (4) is expected to be positive and value of parameter $c_{2}$ is expected to be negative. The abovementioned hypotheses mean that marketwide illiquidity has an effect on average market returns: expected illiquidity has a positive, and unexpected illiquidity - a negative impact. The test has been made using model described in equation (4). The excess market return is computed as a difference between market return (proxied by WIG rate of return) and risk-free rate of return (proxied by one-month Warsaw Interbank Offered Rate (WIBOR 1M)).

The unexpected illiquidity is assumed as a residual $\left(v_{m}\right)$ from $\operatorname{AR}(1)^{7}$ model described in equation (5). The OLS estimation of this model gives following results ( $t$-statistics for parameters are given in parentheses):

$$
\ln A I L L I Q_{m}=1,57414+0,64095 \text { AILLIQ }_{m-1}+v_{m}
$$

Knowing the values of unexpected illiquidity, it is possible to estimate the parameters of the model described in equation (4). The model was estimated using GLS method. Parameters estimated with OLS were highly insignificant, which resulted in poor quality of the whole model (not reported). Estimation of the model provides results as follows ( $t$-statistics for parameters are given in parentheses):

$$
\begin{gathered}
\left(\mathrm{r}_{M}-r_{f}\right)_{m}=-0,00791+0,00223 \ln A I L L I Q_{m-1}-0,00491 \ln A I L L I Q_{m}^{U} \\
(1,7899)(1,7769)
\end{gathered}
$$

As expected, $c_{1}$ is positive and $c_{2}$ is negative, which means that expected illiquidity positively affects market returns and unexpected illiquidity has a negative effect on market returns. It should be noted that the whole model is significant at level 0,03 , hence there is no evidence to reject the hypothesis 1 and 2. This results are consistent with the findings of Amihud, Mendelson and Wood (1990) and Amihud (2002).

7 Amihud (2002) used an autoregressive model with one-period lag (AR(1)) to estimate the unexpected liquidity, but it can be estimated using model with two-period lag (AR(2), see e.g. Kim, Lee (2014)) or more. 


\section{Concluding remarks}

This paper investigates the effect of stock liquidity on returns on the Polish stock market. Using data on all stocks (excluding banks and insurance companies) listed on the Warsaw Stock Exchange, cross-sectional, time-series and pooled cross-sectional time-series models have been estimated. To proxy for liquidity, Amihud illiquidity ratio was computed monthly and annually. The results of the study suggest that less liquid stocks yield higher returns. This effect persists after controlling for size and book-to-market ratio. Presented results also show that liquidity has an effect over time on returns: expected illiquidity positively affects excess returns and unexpected illiquidity lowers excess returns.

To investigate the effect of stock liquidity on returns, at first parameters of crosssectional models have been estimated and averaged through time. Following Litzenberger and Ramaswamy (1979) pooled estimators have been computed as weighted average, with weights inversely proportional to standard errors of cross-sectional estimates. Consistent with expectation, less liquid stocks yield higher returns. This effect persists after controlling for size and book-to-market ratio. Similar results provides estimation of pooled cross-sectional time-series models, as shown in equation (6). However, empirical research has encountered difficulties in finding a satisfactory econometric model, which encourages further studies in this field.

Cross-sectional effect of liquidity on stock returns is not the only one that may occur in the market. Liquidity can be priced over time, which means that improving liquidity lowers stock returns. A test of the effect over time of illiquidity on the excess returns was carried out by regressing excess market returns on expected and unexpected illiquidity in a given month. The results are as follows: expected illiquidity has a positive impact on returns and unexpected illiquidity negatively affects market excess returns.

Presented results possibly reveal the mechanism of pricing of liquidity. Investors expecting illiquidity in the next period, lower the price of transaction to compensate future price impact of trade. That is why the impact of expected illiquidity on returns is positive. In the next period, when liquidity is lower than expected, investors transact with higher price impact, which results in lower returns. This hypothesis is supported by parameters of the model presented in equation (8) and their statistical significance.

In conclusion, presented results suggest that liquidity is priced on the Warsaw Stock Exchange. This is consistent with similar studies of liquidity effects on stock returns on developed equity markets, especially on the U.S. stock exchanges. Results shown in this paper are consistent with Gajdka, Gniadkowska and Schabek (2010) who found the evidence of pricing of liquidity (measured by bid-ask spread) on the WSE.

There are several possibilities to expand this research. This study takes a step to reveal the pricing of liquidity on the Warsaw Stock Exchange. Future research can include a longer time horizon and other methods, e.g. portfolio analysis. Another possible field of the studies is examination of the effect of unexpected liquidity on the cross-section of returns. 


\section{References}

Acharya, V.V., Pedersen, H.L. (2005). Asset pricing with liquidity risk. Journal of Financial Economics, 77 (2), $375-410$.

Amihud, Y. (2002). Illiquidity and stock returns: cross-section and time-series effects. Journal of Financial Markets, 5, 31-56.

Amihud, Y., Mendelson, H. (1986). Asset pricing and the bid-ask spread. Journal of Financial Economics, 17, 223-249.

Amihud, Y., Mendelson, H., Wood, R. (1990). Liquidity and the 1987 stock market crash. Journal of Portfolio Management, 16, 65-69.

Baker, K. (1996). Trading location and liquidity: An analysis of U.S. dealer and agency markets for common stocks. Financial Markets, Institutions, and Instruments, 5 (4), 1-51.

Bekaert, G., Harvey, C.R., Lundblad, C. (2007). Liquidity and expected returns: Lessons from emerging markets. The Review of Financial Studies, 20 (6), 1783-1831.

Będowka-Sójka, B. (2016). Liquidity dynamics around jumps: The evidence from the Warsaw Stock Exchange. Emerging Market Finance and Trade, 52, 2470-2755.

Brennan, M.J., Subrahmanyam, A. (1996). Market microstructure and asset pricing: On the compensation for illiquidity in stock returns. Journal of Financial Economics, 41, 441-464.

Chordia, T., Roll, R., Subrahmanyam, A. (2002). Order imbalance, liquidity, and market returns. Journal of Financial Economics, 65, 111-130.

Datar, V.T., Naik, N.Y., Radcliffe, R. (1998). Liquidity and stock returns: An alternative test. Journal of Financial Markets, 1, 203-219.

Donadelli, M., Prosperi, L. (2011). The equity risk premium: Empirical evidence from emerging markets. Working paper. Retrieved from: http://dx.doi.org/10.2139/ssrn.1893378.

Gajdka, J., Gniadkowska, A., Schabek, T. (2010). Płynność obrotu a stopa zwrotu z akcji na Giełdzie Papierów Wartościowych w Warszawie. Zeszyty Naukowe Uniwersytetu Ekonomicznego w Poznaniu, 142, 597-605.

Garsztka, P. (2011). Konstrukcja portfela akcji z wykorzystaniem ryzyka płynności. In: B. Pawełek (ed.), Osiagnięcia i perspektywy modelowania i prognozowania zjawisk społeczno-gospodarczych (pp. 269-279). Kraków: Wydawnictwo Uniwersytetu Ekonomicznego w Krakowie.

Garsztka, P. (2012). Konstrukcja portfela papierów wartościowych z uwzględnieniem płynności walorów. Zeszyty Naukowe Uniwersytetu Ekonomicznego w Poznaniu, 242, 56-68.

Hasbrouck, J. (2009). Trading costs and returns for U.S. equities: Estimating effective costs from daily data. The Journal of Finance, 64 (3), 1445-1477.

Huberman, G., Stanzl, W. (2005). Optimal liquidity trading. Review of Finance, 9, 165-200.

Kim, S.H., Lee, K.H. (2014). Pricing of liquidity risks: Evidence from multiple liquidity measures. Journal of Empirical Finance, 25, 112-133.

Korajczyk, R.A., Sadka, R. (2008). Pricing the commonality across alternative liquidity measures. Journal of Financial Economics, 87, 45-72.

Kucharski, A. (2009). Badanie szerokości rynku akcji notowanych na polskiej giełdzie. Prace Naukowe UE we Wrocławiu, 60, 235-241.

Kucharski, A. (2010). Stabilność oszacowania szerokości rynku na polskiej giełdzie. Finanse, Rynki Finansowe, Ubezpieczenia, 28, 457-468.

Kyle, A.S. (1985). Continuous auctions and insider trading. Econometrica, 53 (6), 1315-1336.

Lischewski, J., Voronkova, S. (2012). Size, value and liquidity. Do they really matter on an emerging stock market? Emerging Markets Review, 13, 8-25.

Litzenberger, R., Ramaswamy, K. (1979). The effect of personal taxes and dividends on capital asset prices: Theory and empirical evidence. Journal of Financial Economics, 7 (2), 163-195.

Liu, W. (2006). A liquidity-augmented capital assets pricing model. Journal of Financial Economics, 82 (3), $631-671$. 
Marshall, B.R., Young, M. (2003). Liquidity and stock returns in pure order-driven markets: Evidence from the Australian stock market. International Review of Financial Analysis, 12, 173-188.

Milo, W., Wawruszczak, M. (2005). Analiza płynności finansowej GPW w Warszawie. Prace Naukowe AE we Wroctawiu, 1088, 27-35.

Milo, W., Wawruszczak, M. (2006). Płynność finansowa Giełdy Papierów Wartościowych w Warszawie (na przykładzie spółek WIG20). Prace Naukowe AE w Katowicach. Metody matematyczne, ekonometryczne i informatyczne $w$ finansach $i$ ubezpieczeniach, 1, 85-92.

Olbryś, J. (2014). Is illiquidity risk priced? The case of Polish medium-size emerging stock market. Bank i Kredyt, $45,513-536$.

Pastor, L., Stambaugh, R. (2003). Liquidity risk and expected stock returns. Journal of Political Economy, 111 (3), 642-685.

Sadka, R. (2002). The seasonality of momentum: Analysis of tradability. Northwestern University Department of Finance Working Paper No. 277. Retrieved from: http://dx.doi.org/10.2139/ssrn.306371.

\section{PLYNNOŚĆ RYNKU KAPITALOWEGO I STOPY ZWROTU NA GIELDZIE PAPIERÓW WARTOŚCIOWYCH W WARSZAWIE. BADANIE WSTĘPNE}

Streszczenie: $\mathrm{Cel}$ - Na rynkach wysoko rozwiniętych zależność między płynnością akcji a wymaganą przez inwestorów stopą zwrotu jest dobrze udokumentowana. Jednak dla polskiego rynku kapitałowego wciąż brakuje wyczerpujących badań w tym obszarze. Prowadzone dotychczas analizy dla giełdy warszawskiej nie dają jednoznacznych rezultatów (zob. Gajdka, Gniadkowska, Schabek, 2010; Olbryś, 2014). Celem artykułu jest zbadanie zależności między poziomem płynności a stopami zwrotu z akcji na Giełdzie Papierów Wartościowych w Warszawie w latach 2011-2015.

Metodologia badania - Do pomiaru płynności wykorzystany został miernik braku płynności Amihuda. W artykule wykorzystano regresję szeregów czasowych między nadwyżkowymi stopami zwrotu a poziomem płynności rzeczywistej i nieoczekiwanej. Ponadto zastosowano metodę regresji przekrojowej i panelowej do zbadania związku między płynnością akcji a stopami zwrotu.

Wynik - Przeprowadzone badania wykazały, że płynność akcji wpływa istotnie na osiągane stopy zwrotu zarówno w ujęciu czasowym, jak i przekrojowym. Efekt ten utrzymuje się również po uwzględnieniu zmiennych kontrolnych uwzględniających rozmiar oraz relację wartości księgowej do wartości rynkowej spółki.

Oryginalność/Wartość - Autorowi nie są znane badania, w których zastosowano podobne podejście. Zaprezentowane wyniki uzasadniają podjęcie dalszych i bardziej dogłębnych badań relacji między poziomem płynności a stopami zwrotu z akcji na Giełdzie Papierów Wartościowych w Warszawie.

Słowa kluczowe: płynność akcji, stopy zwrotu, GPW w Warszawie, wycena płynności

\section{Cytowanie}

Stereńczak, S. (2017). Stock market liquidity and returns on the Warsaw Stock Exchange: An introductory survey. Finanse, Rynki Finansowe, Ubezpieczenia, 2 (86), 363-374. DOI: 10.18276/frfu.2017.86-30. 